\title{
A TRANSITION TO KNOWLEDGE-INTENSIVE SERVICE ACTIVITIES IN POWER INDUSTRY: A THEORETICAL FRAMEWORK
}

\author{
MIKHAIL V. KOZHEVNIKOV \\ Department of Energy and Industrial Management Systems, Ural Federal University, Russia
}

\begin{abstract}
The current smart energy transition is accompanied by major transformations in the aspects of technology, market, and organization. The intensive adoption of digital technology in energy production, the rapid spread of distributed generation, micro-grids and energy storage and accumulation solutions, and an ever-increasing integration between the energy sector and other critical infrastructure sectors have brought about fundament changes in the relationships between energy companies and the market. This creates a strong demand for versatile support services for these processes. The article makes an attempt to construct a conceptual framework for and to outline the tasks and goals of knowledge-intensive services in the new energy industry. The author provides justification for the key properties of knowledge-intensive services that include adaptability, the capability of self-tuning, a wide use of information and telecommunication technologies, a tendency to use a pro-active approach to systems and process management, and the availability of staff with outstanding qualifications. The author has developed a conceptual model of knowledge-intensive services in the energy sector that makes it possible to group the service segments by the dimensions of "energy market optimization and customer relations", "asset lifecycle management", "organizational flexibility of energy market agents". Recommendations are given as to how to develop knowledge-intensive service activities in energy companies, including through the creation of corporate platforms and smart partnerships with universities and science.
\end{abstract}

Keywords: knowledge-intensive services, information and telecommunication technology, smart energy, technology modernization, critical infrastructure, platform, energy company, conceptual model.

\section{INTRODUCTION}

Over the past few decades, pivotal structural shifts have occurred in the global economic landscape. For a long time, the production of tangible goods was given priority in the economic reproduction of the country, while services were considered to play a secondary role. In other words, it is the commodity composition of industrial output that ensures a stable position of the country in the system of the international division of labor and its economic security, i.e., its resilience during geopolitical crises, while the service sector follows the development of industry and supports the efficiency of industrial production in the broad sense of the word.

Nevertheless, the transition from an industrial economy to a knowledge economy and on to a new digital economy is accompanied with paradigm shifts in corporate business models - from the mass production of standardized tangible products to a diversified range of services that give an additional value to the product offer. As a result, the tertiary sector has started to have a defining impact on the economic sustainability of countries and regions. The impact is determined by globalization, a high level of entrepreneurial activity in service markets [1], [2], a stable growth in the consumption of services as a distinct product [3], [4], unprecedented employment rates in service businesses [4]-[6], and a higher degree of innovation as compared to traditional industries [7]-[10]. Annual growth rates for value added in services exceed those in manufacturing in the overwhelming majority of countries 
(Fig. 1). In some countries (Great Britain, France, US), the share of the tertiary sector in GDP is nearly $80 \%$.

However, the boundaries of the definition of "tertiary sector" that was introduced by Fisher [11] and later refined by Clark [12] are very conditional. International industrial classifications such as NACE, ISIC or NAICS categorize a wide range of various activities as the tertiary sector. This does not fully reflect the profound transformation of the service industry. A close integration of services and manufacturing, rapid technological modernization of economies, sweeping digitization and personalization, the processes of service externalization result in the sprouting of new service segments, with so-called "knowledge-intensive service" that serves as a "facilitator of innovations" being the most interesting one.

Research in the area began to emerge in the 1990s and has largely been of general nature. A few cases were dedicated to certain aspects of knowledge-intensive services in the IT industry, the oil and gas sector, health care and pharmaceuticals, and agriculture [13]-[17]. Meanwhile, it is the sectoral affiliation that fills knowledge-intensive service with specific and meaningful tasks and determines its organizational features. We shall consider these features using the case of the energy sector as one of the most complex industries that is going through dramatic transformations affecting both production and technology and relations between energy companies and consumers against the backdrop of a new industrial revolution.

\section{THEORETICAL BACKGROUND FOR STUDIES OF KNOWLEDGE-INTENSIVE SERVICE}

Knowledge-intensive services have been widely adopted in hi-tech industries such as pharmaceutical and medical devices manufacturing, electric power generation and the oil and gas industry, machinery manufacturing, computer and peripheral equipment manufacturing, wired and wireless telecommunications; semi-conductor and other electronic component manufacturing; the aerospace industry; geolocation services; engineering and consulting; electric equipment manufacturing; chemical manufacturing; industrial design [14]. The most authoritative researchers of knowledge-intensive service [18]-[21] define it as an independent segment of specialized business services that have a high degree of the information and intellectual elements in their value. Knowledge-intensive services can, for example, cover software development, management consulting, scientific and technical

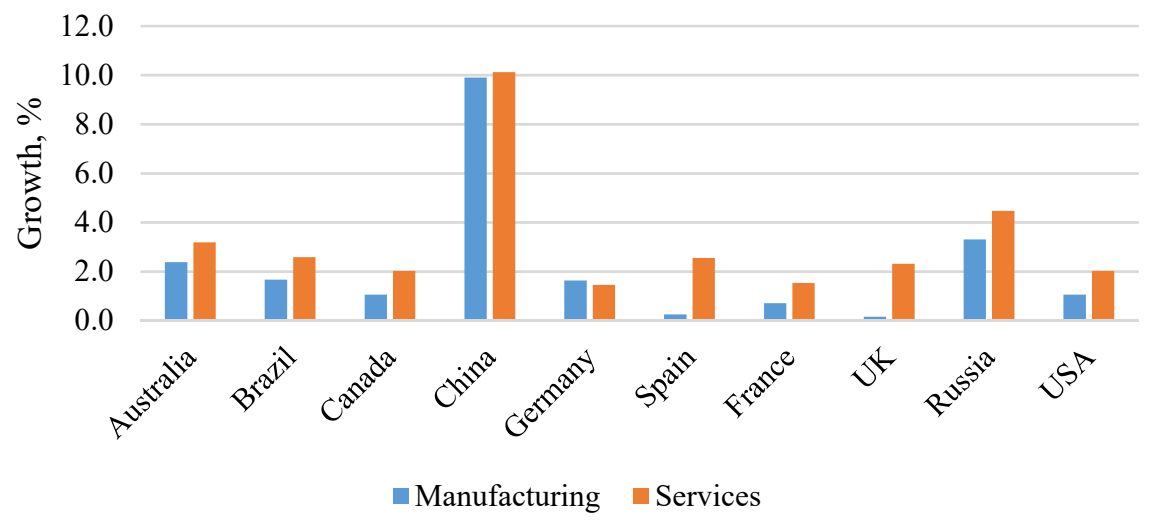

Figure 1: Growth rates for added value in manufacturing and service in 2000-2017. 
evaluation; business audit; marketing analysis and foresight; complex machinery repair; engineering, data storage and analysis, telecommunication services; personnel training. Kox and Rubalcaba [19] and Wong and He [22] note that knowledge-intensive services are mainly traded in business-to-business transactions that involve two types of parties:

- developers of technological know-how, scientific studies, intellectual property that can be converted into various marketable forms, and

- business consumers of "advanced knowledge" who seek to become leaders of innovation in the market by performing continuous content analysis and attracting experts with new competencies.

The process of producing knowledge-intensive services depends on: 1) the entrepreneurial activity of the service company; 2) its institutional status; 3) technology cooperation with knowledge transfer centers; 4) the degree of industrial/corporate dispersion. Unlike traditional services that can be delivered in a standardized way in standalone business units or branches of the company, knowledge-intensive services need to be organizationally distributed.

The interdisciplinary nature of the process of producing knowledge-intensive services makes it impossible to keep the service function within a specific organizational cell because intangible and tacit knowledge needs to be exchanged constantly, both internally and externally.

This is what makes knowledge-intensive services a kind of interface between providers and clients, a zone when advanced knowledge is concentrated and solutions to the most complex and extremely specific problems are found in the most efficient, timely and comfortable way. The research element becomes an essential part of knowledge-intensive services [23].

The process of knowledge-intensive service consumption is affected by the so-called "socio-technological paradox": customers simultaneously have negative and positive expectations in relations to one and the same effect (labor productivity, market expansion, business process optimization, innovative development). At the same time, the customer usually wants to be present at the delivery of the service (to monitor it, get relevant information and even provide assistance to the contractor). There occurs the co-opetition effect - a combination of cooperation and competition between the parties involved in service processes for the right to select the best way of service delivery, which motivates contractors to constantly work on the quality of service processes [24]-[26]. At the same time, customers' engagement in service delivery gives businesses an opportunity to create platforms that scan the market for new preferences, rapidly design new service, rapidly tests them and brings to the market and promptly collects feedback and adds improvements to the ultimate service [27].

The rise of knowledge-intensive services has been particularly strong in the areas where there is an abundance of emerging technologies (Table 1) and related digital eco-systems. Such segments set forth new requirements to services as a support function for production and business processes. A digital eco-system alone does not turn out a product; it is created as a preemptive response to disruptive events in order to minimize the adverse effect of market, social or technological risks [28]. For new production technologies to function effectively, they need to be surrounded by a network of adaptive self-tuning services that make it possible to monitor the parameters of the system on a real time basis as well as to predict its behavior in the future.

The fundamental requirement that the provider of a knowledge-intensive service needs to meet is that the competencies of the service personnel must be more diversified than in traditional manufacturing firms. Gölpek [7] observes that service personnel must have a 
Table 1: New manufacturing technologies and ancillary knowledge-intensive services.

\begin{tabular}{|c|c|c|c|}
\hline Technology & $\begin{array}{c}\text { Traditional technology } \\
\text { and equipment }\end{array}$ & $\begin{array}{l}\text { New technology } \\
\text { and equipment }\end{array}$ & $\begin{array}{l}\text { Types of knowledge- } \\
\text { intensive services }\end{array}$ \\
\hline $\begin{array}{l}\text { Technology for } \\
\text { organization } \\
\text { and } \\
\text { management }\end{array}$ & $\begin{array}{l}\text { Systems engineering } \\
\text { approaches, LEAN }\end{array}$ & $\begin{array}{l}\text { Smart or cloud } \\
\text { manufacturing, } \\
\text { digital firms }\end{array}$ & $\begin{array}{c}\text { Data storage, cyber } \\
\text { security, digital consulting, } \\
\text { knowledge management }\end{array}$ \\
\hline $\begin{array}{l}\text { IT-systems } \\
\text { supporting } \\
\text { product } \\
\text { lifecycle }\end{array}$ & CAD, CAE, CAM / PDM & $\begin{array}{l}\text { CAx for additive } \\
\text { technologies, } \\
\text { M2M, cloud } \\
\text { technologies }\end{array}$ & $\begin{array}{c}\text { Spatial modeling of } \\
\text { complex objects; } \\
\text { maintenance services for } \\
\text { smart industrial } \\
\text { management systems }\end{array}$ \\
\hline $\begin{array}{l}\text { Fabrication } \\
\text { technology }\end{array}$ & Machinery manufacturing & $\begin{array}{c}\text { Additive } \\
\text { manufacturing }\end{array}$ & $\begin{array}{c}\text { 3D prototyping, } \\
\text { stereolithography, selective } \\
\text { laser melting }\end{array}$ \\
\hline $\begin{array}{l}\text { Automation } \\
\text { equipment and } \\
\text { technology }\end{array}$ & $\begin{array}{c}\text { Relays, switches, sensors } \\
\text { power electronics }\end{array}$ & Industrial robots & $\begin{array}{c}\text { Computer simulator, } \\
\text { service robots, CNC } \\
\text { machining }\end{array}$ \\
\hline $\begin{array}{l}\text { Advanced } \\
\text { materials }\end{array}$ & Metals, plastics & $\begin{array}{l}\text { Composite } \\
\text { materials with } \\
\text { programmable } \\
\text { properties }\end{array}$ & Materials testing \\
\hline Logistics & Push-and-Pull Scheduling & $\begin{array}{c}\text { Multi-agent } \\
\text { logistic systems }\end{array}$ & Virtual planning \\
\hline Transport & $\begin{array}{c}\text { Mass production of } \\
\text { transportation vehicles } \\
\text { power by alternative fuels }\end{array}$ & $\begin{array}{l}\text { Smart electric } \\
\text { transport systems }\end{array}$ & $\begin{array}{c}\text { Adaptive traffic control, } \\
\text { smart parking; services } \\
\text { supporting the trading of } \\
\text { energy between electric } \\
\text { transport and energy } \\
\text { market }\end{array}$ \\
\hline
\end{tabular}

thorough understanding of the functional peculiarities of new manufacturing technologies through all stages of their lifespan. Such technologies usually require constant human-machine interaction by means of special service interfaces, which means round-the-clock supervision of the operation of complex manufacturing systems and customers who use new manufacturing technologies as intended.

Knowledge-intensive services can therefore be considered from different perspectives. On the one hand, it is a certain type of complex services (engineering and technical; information, consulting, education, management ones) that have a new unique value for customers and that cannot be produced without the participation of highly professional experts possessing advanced knowledge of technology and without infrastructure, including research infrastructure, for constant generation and renewal of such knowledge. On the other hand, knowledge-intensive service can be defined as a specific segment of the service market that is characterized by service processes' embeddedness in production. This determines the heterogeneous composition of market players and constant involvement of both the provider and the customer in the process of service delivery.

The "watershed" between traditional and knowledge-intensive services lies in: 
- the way the service is provided. Traditional services are delivered using the same means, instruments and personnel regardless of the service subject. Knowledgeintensive services call for a constant search for new methods, the development of customized solutions, team rotations, and external intellectual and machine capital;

- commercial value. Traditional services ensure the comfortable and efficient running of the main production process, product or system without any considerable changes to their key components. Knowledge-intensive services are highly innovative and bring profound changes to business models and the behavior of economic agents that interact in the process of service design and delivery;

- $\quad$ provision of analytical support for service delivery. The delivery of traditional and knowledge-intensive services lasts over long periods of time, and the quality of the service cannot be assessed until the delivery is complete. The use of analytical instruments, software and diagnostic programs for actual and remote monitoring can, however, enable the contractor to get a detailed snapshot of the phases of knowledge-intensive service production, to forecast potential risks and make appropriate adjustments.

\section{CONCEPTUAL MODEL OF KNOWLEDGE-INTENSIVE SERVICE IN THE ENERGY SECTOR}

The growing role of the service sector in energy has to do with a number of internal and external factors. On the one hand, global energy business is moving towards a structural model in which energy companies are increasingly focused on energy production management, asset management and projects of building new energy facilities or refurbishing existing ones. The majority of associated works aimed at technological search, forecasting market and customer behavior, engineering, and repair and maintenance of complex energy equipment, and logistics are executed by third party service companies.

Additionally, many energy companies cannot afford to have skilled employees and knowledge-intensive equipment for performing hi-tech works amid a transition to a new energy paradigm. This is particularly true when demand for such works is intermittent. Using the services provided by specialist service organizations enables energy businesses to shift the risk of employee and equipment underutilization to them. Such an approach enables service organizations to focus on performing selected complex technological operations and utilize the available personnel and their know-how to the full.

At the same time, the energy sector that is naturally prone to inertia is under pressure from an innovation avalanche triggered by Industry 4.0. This sets the background for three major trends that, according to experts from Bain\&Company, determine the need for building knowledge-intensive service infrastructure in the energy sector: 1) electrification of an overwhelming majority of production processes in various industries; 2) decentralization as a form of independent market behavior of customers, and 3) digitalization that allows open communication between the grid operator and any of its elements (Table 2).

Industry-specific services are entering a new development stage; their scale is growing drastically. Knowledge-intensive services are becoming the key driver and responsibility center of progress in energy, focusing on the adaptation of new technologies, digital ones above all, to the desirable market structure. The authors could identify three key application areas for knowledge-intensive services in the modern energy sector (Table 3).

Here are some examples of digital services that have shown the best growth in the global energy market [30]-[32]: 
- Alliander (Netherlands) is currently piloting projects that match supply and demand at the local level in real time. Partnering with CGI, an IT solutions provider, Alliander is using its PowerMatcher software as the foundation for Realtime Energy eXchange (REX). This is expected to be rolled out to 800,000 streets across 14 municipalities. At a household level, REX enables nonessential appliances to be run at times when supply is abundant and power prices are low. Alliander and CGI are also researching potential ways for REX to take advantage of the growing increase in electric car ownership in the Netherlands, for example by using the batteries of electric vehicles as a flexible storage solution.

- PowerShop (Australia) is an integrated energy solution provider, offering consumers the ability to monitor and purchase electricity online, on mobile and via social media. From their smartphones, customers can monitor home energy consumption and choose the source of their electricity, such as from alternative energy projects or large power plants.

- US company General Electric has recently launched its flagship knowledgeintensive service, Predix, a platform for industrial-scale analytics, which connects machines, sensors, control systems and devices to capture and interpret data from manufacturing systems. Predix is a highly flexible product, with its application including monitoring and diagnostics for rail transportation, cloud imaging for healthcare, and nondestructive testing remote collaboration for oil and gas utilities. Predix is an example of a unique knowledge-intensive service platform that a big energy corporation was able to create through cooperation with partners from adjacent markets, thus adding advanced experience, knowledge and competencies to its own practice.

The traditional grid-based power industry has also seen the emergence of areas in which knowledge-intensive services are of critical importance. This, above all, refers to new principles of asset management and repair and maintenance arrangements for power plants and transmission networks (boilers, turbines, generators, power transformers, transmission lines, switchgear, breakers, nuclear power reactors, penstocks etc.) The model of knowledgeintensive services for repair and management builds upon a strategy of risk and performance management that envisages ranking equipment by reliability, analyzing the state of a component and the piece of machinery as a whole, assessing the risk of failure and potential damage from the economic and environmental points of view and technological implications.

Technologically, the process could be described as follows: RFID tags are attached to energy equipment. The tags capture machine performance data that can be read by shop floor workers using tablet PCs or smartphones or can be transferred to a data storage hub in realtime mode. The data is then analyzed using a Big Data technology and an equipment failure forecast is generated in real-time mode, making it possible to timely fix malfunctioning units, thus reducing potential losses from downtime. In order to switch over to the model, energy companies have to use modern diagnostics tools and predictive analytics.

A conceptual model of knowledge-intensive services in the energy sector is depicted in Fig. 2 The goal is to demonstrate the interconnectedness of various types of knowledgeintensive services and to reflect the scale of the service industry. The cube has been selected as a visual metaphor for the model. The cube is split into layers along the $\mathrm{X}$ axis, indicating the corporate, regional and industrial service segments. Each axis is divided into three, representing the complexity of delivering certain knowledge-intensive services. The division also makes it easier to classify individual groups of services within a coordinate system. 
A comprehensive implementation of the model is an extremely laborious task. In fact, it means building large energy service infrastructure based on systemic principles. Such infrastructure should be synchronized with technology and set the "rules of the game" for different energy market stakeholders, who are used to acting in line with their own business, legal and financial laws. Some countries, e.g. the US, Great Britain, Germany, and Canada, have been successfully embracing the idea of the system configuration of the market for knowledge-intensive services. This usually means creating technology interfaces that are universal for all market participants, a corresponding innovative and regulatory environment, corporate and municipal support tools for individual projects. That brings closer the interests of energy companies, contracts and consumers to a certain degree.

The author is convinced that the required infrastructure should be built within the dimensions of the presented conceptual model that indicate several closely connected areas.

1. As regards energy market optimization.

- Encouraging competition between energy market participants - especially energy service companies and energy distributors - operating in the segments of the value chain that are the closest to the consumer.

- Ensuring access of various categories of consumers (for example, owners of electric vehicles) to the digital infrastructure of the market in order to enable vehicle-to-grid operations.

- Incentives (in the form of legal and financial mechanisms) for technology entrepreneurship that is viewed as the driver of the industry-specific innovative process.

- A more flexible tariff policy and legalization of dynamic pricing in order to enable the implementation of demand side and consumption management programs.

As part of this set of measures, one needs to highlight legal provisions for the mass adoption of the internet of things, and the processing of consumers' energy data [29], [33][36]. All too often, outside actors of the telecommunications market who are capable of providing such services have limited or no access to the required information. This has to do with a risk of cyber security infringements and data breaches, which could much more serious implications in the energy sector as compared to other industries due to the need to ensure the reliability and stability of power supply. At the same time, this barrier impedes the development of service companies that make it possible to monitor and control the market in which the number of participants - both energy producers and consumers - has been growing drastically.

2. As regards asset lifecycle management.

- Creation of joint platforms of energy companies, energy equipment producers and telecom businesses for the sake of a transition to advanced forms of repair and maintenance and intelligent reliability management.

- Development of a universal system of communication between household energy networks and top-level dispatch control centers that is based on unified data models.

- Adoption of forward-looking technical standards that harmonize the development of various elements of the grid - from low-voltage networks to operators in all sectors, from power plants to end consumers, from markets to technological processes. 


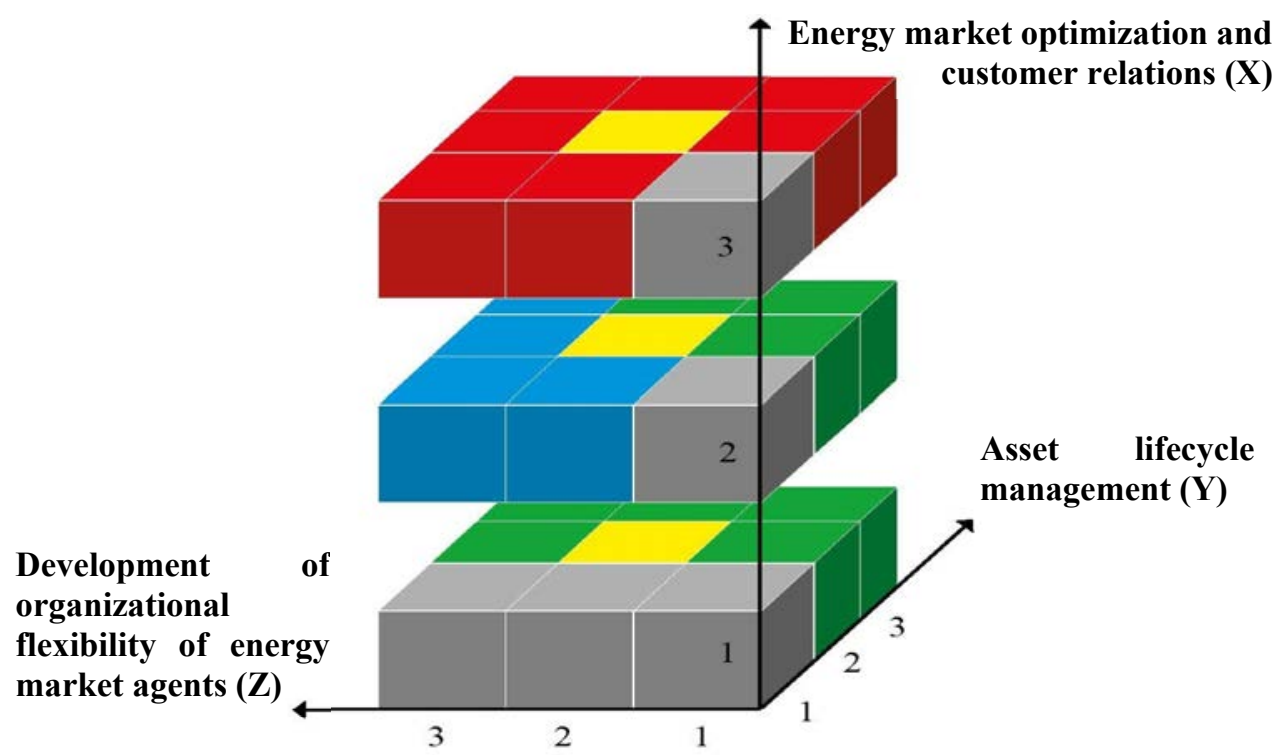

Grey Zone - IT-services

$(1,1,1)$ Services supporting business processes and customers' interaction with energy markets

$(2,1,1) \quad$ (applications, software, data aggregation solutions, data bases)

$(1,1,2)$ In-house consulting and R\&D-services

$(1,1,3)$ Development of organizational flexibility of energy market agents

Yellow Zone - services for personnel training and competency development

Green Zone - services supporting the adoption of new principles of repair and maintenance of energy equipment, revamping and technical upgrading of energy facilities

$(1,2,1)$ Use of robots for individual operations and mechanical works

$(1,3,1)$ Remote monitoring and energy equipment performance analysis

$(1,2,3)$ Digital twins

$(1,3,2)$ Optimization of manufacturing logistics

$(1,3,3)$ Digital analytics and intelligent planning

$(2,2,1)$ Servicing of smart devices and charging infrastructure, incl. in transportation

$(2,3,1)$ Energy service contracts for energy conservation

$(2,3,2)$ General engineering using EPCM and BOOT schemes

Blue Zone - demand side management services

$(2,1,2)$ Smart metering

$(2,1,3)$ Electricity storage

$(2,2,3)$ Virtual power plants

$(2,3,3)$ Real-time demand response and consumption management platforms

Red Zone - "institutional" services

$(3,1,2)$ Digital financial services

$(3,2,1)$ Experimental platforms for testing new technologies

$(3,1,3)$ Cyber security and energy data storage

$(3,3,1)$ Digital consulting

$(3,2,3)$ Industry and cross-industry knowledge transfer, including monitoring mechanisms for

$(3,3,2)$ Intelligent reliability management

$(3,3,3)$ Analytical platforms for balancing supply and demand

Figure 2: A conceptual model of knowledge-intensive service in the energy sector. 
- A transition to state regulation models that encourage the creation of soft assets by energy companies rather than hard assets investments.

The latter step might seem controversial, but it has to be noted that digitalization in and of itself is an extremely costly process (just imagine the cost (including downtime cost) of fitting the boilers/turbines of power plants with digital sensors or building a chain of charging stations for electric vehicles in a city) that is bound up with creating a supporting service infrastructure, which entails high fixed and variable costs. That's why many energy companies continue to build their business on maximizing the sales of their main product electricity and thermal energy. For some types of knowledge-intensive services, such as EPC, EPCM, and BOOT schemes in engineering and construction of energy facilities, this barrier does not play the key role, but it does when it comes to implementing demand side management programs in a region or executing a complex energy service contract.

3. As regards greater organizational flexibility of energy market agents.

- Designing a methodology for integrated management of new grid facilities: virtual power plants, digital substations, flexible power distribution systems, energy storage systems, power supply networks for smart buildings, intelligent electric transport infrastructure.

- Adoption by energy companies and industry organizations of proactive management based on the early detection of opportunities and threats, methods of predictive analytics, principles of systems engineering and agile methods.

- Building close cooperation between energy companies, universities and science for conducting breakthrough research, knowledge generation and transfer, construction of new experimental platforms for performing tests, and commercializing innovations and bringing them to the market.

- Creation of a system of anticipatory training of personnel and teams for the technology modernization of the energy sector.

The latter issue is unfortunately often overlooked in both theory and practice. The author is convinced that without having a system that makes it possible to predict the competencies that will soon be required and to nurture them in personnel it is pointless to speak about moving on to a new energy paradigm and to knowledge-intensive service at its core in particular.

The experience of a team of experts from Ural Federal University, including the author, shows that the problem can be solved by creating corporate platforms, with initiative coming from energy companies in cooperation with educational and scientific organizations.

The pilot testing of the projects "Technological Leadership Incubator" and "Training for Breakthrough Teams" on the premises of several Russian energy companies confirms the idea that the infrastructure of knowledge-intensive energy services must include centers of excellence that have the required scientific and technical background and ensure a transition from $R \& D$ results to services with competitive and replicable properties and perform the verification of the declared properties of new manufacturing technologies for potential customers.

\section{CONCLUSION}

The present study is aimed at giving a comprehensive picture of the complexity and multifacetedness of knowledge-intensive services in the energy sector that is experiencing an 
inflow of digital technologies in production, the growth of distributed generation and microgrids, the emergence of numerous cogeneration energy facilities that require functional and technological compatibility, and new markets, for example, for energy storage devices. At the same time, consumers are getting increasingly proactive and the sector itself is integrating with other critical infrastructure industries.

The problem of knowledge-intensive services in the energy sector has found little coverage in academic literature and is at an early stage of its development in practice. Consequently, the list of identified barriers and recommendations is by no means exhaustive. Additional theoretical and empirical analysis is required to reveal the interdisciplinary nature of the subject in a more profound way and to verify the parameters of the proposed conceptual model of knowledge-intensive services. The author views as promising and intends to work on the following areas.

4. Methodology of developing flexible manufacturing and organizational systems ensuring pre-emptive response to external challenges and threats in the energy sector.

5. Market platforms and eco-systems in the energy sector as the implementation of new forms of relationships between producers and consumers of energy services.

6. Cross-industry incentive mechanisms for competition in the market of knowledgeintensive energy services.

7. Systems of knowledge transfer in the "energy business - universities" chain to facilitate anticipatory development of competencies and training of skilled personnel.

\section{ACKNOWLEDGEMENT}

The work was supported by Act 211 of the Government of the Russian Federation, contract № 02.A03.21.0006.

\section{REFERENCES}

[1] Growth in Services, Fostering Employment, Productivity and Innovation, OECD, 2005. www.oecd.org/economy/34749412.pdf. Accessed on: 20 Aug. 2018.

[2] Nählinder, J., Innovation and Employment in Services. The case of Knowledge Intensive Business Services in Sweden, 2005. www.diva-portal.org/smash/get/ diva2:20573/FULLTEXT01.pdf. Accessed on: 20 Aug. 2018.

[3] Sultan, M., The Tertiary Sector Is Going to Dominate the World Economy; Should We Worry? Online. https://mpra.ub.uni-muenchen.de/14681/1/MPRA_paper_14681.pdf. Accessed on: 20 Aug. 2018.

[4] Buera, F.J. \& Kaboski, J.P., The Rise of the Service Economy. American Economic Review, 102(6), pp. 2540-69, 2012.

[5] Preissl, B., Service sector dynamics and service regulation, 2000. Online. www.tips.org.za/research-archive/trade-and-industry/trade-growth-

dynamics/item/92-service-sector-dynamics-and-service-regulation. Accessed on: 20 Aug. 2018.

[6] Johnston, A. \& Huggins, R., Regional growth dynamics in the service sector: The determinants of employment change in UK regions, 1971-2005. Growth and Change, 49(1), pp. 71-96, 2018. DOI: 10.1111/grow.12221.

[7] Gölpek, P., Service sector and technological developments. Procedia-Social and Behavioral Sciences, 181, pp. 125-130, 2015. DOI: 10.1016/j.sbspro.2015.04.873. 
[8] Preissl, B., Research and technology organisations in the service economy. developing analytical tools for changing innovation patterns. Innovation. The European Journal of Social Science Research, 19(1), pp. 131-146, 2006.

DOI: 10.1080/13511610600608039.

[9] Pino, G., Capestro, M., Guido, G., Tomacelli, C. \& Abate, M., Knowledge-intensive services and local development: An empirical analysis of networks, channels and customization processes. Local Economy, 31(3), pp. 359-376, 2016. DOI: $10.1177 / 0269094216642750$.

[10] Shi, X., Wu, Y. \& Zhao, D., Knowledge intensive business services and their impact on innovation in China. Service Business, 8(4), pp. 479-498, 2014. DOI: 10.1007/s11628-013-0202-1.

[11] Fisher, A.G.B., Primary, secondary and tertiary production. Economic Record, 15, pp. 24-38, 1939.

[12] Clark, C., The Conditions of Economic Progress, Macmillan: London, p. 504, 1940.

[13] Martinez-Fernandez, M.C., Soosay, C., Krishna, V.V., Turpin, T. \& Bjorkli, M., Knowledge-Intensive Service Activities (KISA) in Innovation of the Software Industry in Australia, 2005. Online. www.uws.edu.au/_data/assets/pdf_file/0014/33431/KISA_Innovation_of_the_Software_Industy_in_Australia.pdf. Accessed on: 20 Aug. 2018.

[14] Knowledge-Based Industries (KBI). Online. www23.statcan.gc.ca/imdbbmdi/document/2514_D2_T9_V1-eng.pdf. Accessed on: 20 Aug. 2018.

[15] Miozzo, M. \& Grimshaw, D., Modularity and innovation in knowledge-intensive business services: IT outsourcing in Germany and the UK. Research Policy, 34(9), pp. 1419-1439, 2005. DOI: 10.1016/j.respol.2005.06.005.

[16] Hyppönen, H., Saalasti-Koskinen, U., Perala, M-L. \& Saarikalle, K., KnowledgeIntensive Service Activities (KISA) in Health and Social Care Innovation Process: Towards Seamless care for older people in Kuopio Home Care. Online. www.oecd.org/sti/inno/34745295.pdf. Accessed on: 20 Aug. 2018.

[17] Kryukov, V.A. \& Tokarev, A.N., Features of spatial development of oil and gas service: global trends and lessons for Russia, [in Russian]. Region: Economics and Sociology, 3, 189-214, 2017. DOI: 10.15372/REG20170310.

[18] Miles, I. \& Boden, M., Are Services Special? Services and the Knowledge-based Economy, Routledge: London, p. 285, 2000.

[19] Kox, H. \& Rubalcaba, L., Business services and the changing structure of European economic growth. CPB Memorandum, 183, 2007, Online. https://mpra.ub.unimuenchen.de/3750/1/MPRA paper 3750.pdf. Accessed on: 20 Aug. 2018.

[20] Eichengreen, B. \& Gupta, P., The two waves of service sector growth. Oxford Economic Papers, 65(1), pp. 96-123, 2013.

[21] Homburg, C., Workman, J.P. \& Jensen, O., Fundamental changes in marketing organization: The movement toward a customer-focused organizational structure. Journal of the Academy of Marketing Science, 28(4), pp. 459-478, 2000. DOI: $10.1177 / 0092070300284001$.

[22] Wong, P.-K. \& He, Z.-L., A comparative study of innovation behaviour in singapore's kibs and manufacturing firms. The Service Industries Journal, 25(1), pp. 23-42, 2005. DOI: $10.1080 / 0264206042000302397$.

[23] Muller, E. \& Doloreux, D., The key dimensions of knowledge-intensive business services (KIBS) analysis: a decade of evolution, Fraunhofer Institute for Systems and Innovation Research (ISI), 2007. Online. www.econstor.eu/obitstream/10419/29335/ 1/610017543.pdf. Accessed on: 20 Aug. 2018. 
[24] Allmendinger, G. \& Lombreglia, R., Four strategies for the age of smart services. Harvard Business Review, 83, pp. 131-145, 2005.

[25] Wunderlich, N.V., von Wangenheim, F. \& Bitner, M.J., High tech and high touch: a framework for understanding user attitudes and behaviors related to smart interactive services. Journal of Service Research, 11, pp. 1-18, 2012.

[26] Vuori, E.K., Knowledge-intensive service organizations as agents in a business ecosystem. Proceedings of ICSSSM '05, 2, pp. 908-912, 2005. DOI: 10.1109/ICSSSM.2005.1500123.

[27] The New Zealand Sectors Report 2014, Knowledge-Intensive Services. Online. www.mbie.govt.nz/info-services/sectors-industries/sectors-reports-series/pdf-imagelibrary/knowledge-intensive-services-report/knowledge-intensive-services-report.pdf. Accessed on: 20 Aug. 2018.

[28] Rzevski, G., Complexity as the defining feature of the 21 st century. International Journal of Design \& Nature and Ecodynamics, 10(3), pp. 191-198, 2015. DOI: 10.2495/DNE-V10-N3-191-198.

[29] The Future of Electricity, New Technologies Transforming the Grid Edge. Online. www3.weforum.org/docs/WEF_Future_of_Electricity_2017.pdf. Accessed on: 20 Aug. 2018.

[30] Digital Transformation of Industries, Electricity Industry. White Paper, 2016. Online. www.accenture.com/t20170411T120540Z_w__us-

en/_acnmedia/Accenture/Conversion-Assets/WEF/PDF/Accenture-ElectricityIndustry.pdf. Accessed on: 20 Aug. 2018.

[31] Bessa, R.J. \& Matos, M.A., The role of an aggregator agent for EV in the electricity market. 7th Mediterranean Conference and Exhibition on Power Generation, Transmission, Distribution and Energy Conversion (MedPower 2010), pp. 1-9, 2010. DOI: $10.1049 / \mathrm{cp} .2010 .0866$.

[32] Weber, G., Mateescu, R.M., Lange, S. \& Rauch, M., Knowledge intensive business services (KIBS) in the context of changing energy economics in Germany. Amfiteatru Economic, 18(41), pp. 89-103, 2016.

[33] Quéré, S., Delmas-Patterson, G. \& Berezin, A., A new paradigm of governance for a carbon-pricing system. International Journal of Energy Production and Management, 1(2), pp. 192-205, 2016. DOI: 10.2495/EQ-V1-N2-192-205.

[34] Digital Economy: Global Trends and Practice of Russian business, [in Russian]. Analytical Report, National Research University "Higher School of Economics." Online. https://imi.hse.ru/pr2017_1. Accessed on: 20 Aug. 2018.

[35] Annunziata, M. \& Bell, G., Powering the Future. Leading the digital transformation of the power industry, 2015. Online. www.res4med.org/wp-content/uploads/2017/05/ digital-energy-transformation-whitepaper.pdf. Accessed on: 20 Aug. 2018.

[36] Booth, A., Mohr, N. \& Peters, P., The digital utility: New opportunities and challenges, 2016. Online. www.mckinsey.com/industries/electric-power-and-natural-gas/ourinsights/the-digital-utility-new-opportunities-and-challenges. Accessed on: 20 Aug. 2018. 